\title{
Colorectal cancer biomarkers and their impact on the clinical practice
}

\author{
Biomarcadores de câncer colorretal e seu impacto na prática clínica
}

James Crespo ${ }^{1,2}$, Ana Paula Victorino ${ }^{1,2}$, Kelly Araujo ${ }^{1,2}$, Luiz Henrique Araujo 1,2®י, Fernando Meton de Alencar Camara Vieira ${ }^{1,2}$

\begin{abstract}
Colorectal cancer (CRC) holds third place in the global ranking of malignancies worldwide. Patients with CRC commonly show distinct outcomes and treatment responses due to their biological features and tumoral biomarkers. This review explores the repertoire of molecular biomarkers in CRC, comprised of chromosomal aberrations and genomic instability and genetic mutations. We also underline the stratification of CRC patients into four clinically defined subsets: CMS1 (MSI, immune); CMS2 (canonical); CMS3 (metabolic); and CMS4 (mesenchymal), as well as novel techniques to be applied very soon in the field, such as cell-free DNA, tumor mutational burden, and microbiome profiling.
\end{abstract}

Keywords: Biomarcadores; Genômica; Prognóstico; Agentes antineoplásicos; Neoplasias colorretais.

\begin{abstract}
RESUMO
O câncer colorretal (CCR) ocupa o terceiro lugar no ranking mundial de doenças malignas. Pacientes com CCR geralmente apresentam resultados e respostas ao tratamento distintos devido às suas características biológicas e biomarcadores tumorais. Esta revisão explora o repertório de biomarcadores moleculares no CCR, composto por aberrações cromossômicas e instabilidade genômica e mutações genéticas. Também destacamos a estratificação dos pacientes com CCR em quatro subconjuntos clinicamente definidos: CMS1 (MSI, imune); CMS2 (canônico); CMS3 (metabólico); e CMS4 (mesenquimal), bem como novas técnicas a serem aplicadas muito em breve na área, como DNA livre de células, carga mutacional tumoral e perfil do microbioma.
\end{abstract}

Descritores: Biomarcadores; Genômica; Prognóstico; Agentes antineoplásicos; Neoplasias colorretais.

1. Americas Centro de Oncologia Integrado, Medical Oncology - Rio de Janeiro - RJ - Brazil.

2. Instituto COI, Medical Oncology - Rio de Janeiro - RJ - Brazil.

Financial support: none to declare.

Conflicts of interest: The authors declare no conflict of interest relevant to this manuscript.

Correspondence author: James Crespo

E-mail: jamescrespo@americasoncologia.com.br 


\section{INTRODUCTION}

According to the World Health Organization, there are about 1.9 million colorectal cancer (CRC) cases worldwide, being the third place in the global ranking of malignancies. ${ }^{[1]}$ CRC has favorable prognosis when detected in early stages with relative survival of $65 \%$ in five years (91\% for localized and 14\% metastatic tumors, approximately). ${ }^{[2]}$ These tumors can develop in different anatomical sites (ascending colon, transverse colon, descending colon, sigmoid colon, and rectum) and show distinct clinical and biological features. $^{[3-6]}$ Nonetheless, metastatic CRC (mCRC) is understood as a unique disease regardless of its origin.

There are many critical clinical aspects to define prognosis and treatment in CRC. Tumor location can be correlated to outcome, ${ }^{[7-9]}$ although the underlying reasons are still under discussions, like its embryonic origin and microbiome divergence. ${ }^{[10-12]}$ Also, tumors with abundant extracellular mucin content drive patients into worse outcome. About 5-15\% of CRC are classified as mucinous colorectal adenocarcinoma and are associated with poor survival, ${ }^{[13]}$ increased chance of metastasis, ${ }^{[14]}$ and less chance of response to chemotherapy. ${ }^{[15,16]}$. When mucin is located intracellularly, pushing the nucleus aside, CRC is understood as signet ring cell carcinoma (SRCC) - a rare subset representing 1\% of all cases and related to worse prognosis when compared to other histological subtypes. ${ }^{[17,18]}$ In addition, the evaluation of non-invasive glycoprotein tumor markers in peripheral blood, such as CEA, CA19-9, and CA125, has been largely used for outcome assessment and patient monitoring. ${ }^{[19,20]}$

Overall survival (OS) of patients with CRC has been increasing over the last years, given remarkable advances with novel therapies. ${ }^{[21]}$ Most cases require surgery to remove the primary tumor and, if necessary, the metastasis, which might be associated with radiotherapy and chemotherapy as neoadjuvant or adjuvant treatment. ${ }^{[22,23]}$ However, several targeted therapies have been approved by Food and Drug Administration (FDA) since the last decade, including small molecule inhibitors of EGFR pathway-related key proteins (EGFR, HER-2, and BRAF), angiogenesis inhibitors (anti-VEGF/VEGFR), and more recently, immune checkpoint inhibitors (anti-PD-1). ${ }^{24,25]}$ These novel drugs were successfully associated with long-lasting response, prolonged survival, and reduced toxicity compared to conventional therapeutic options. Nevertheless, only a subset of patients benefits from these new drugs.

Herein, we discuss relevant molecular biomarkers in CRC that either are being routinely evaluated in the clinic or will be incorporated in short-term, mainly in metastatic disease. Our main focus is reviewing those clinical biomarkers with emphasis on molecular alterations, their hallmarks, and how they drive us to perform patients' prognosis stratification and identification of drug-responders.

\section{Chromosomal aberrations and genomic instability}

Genome instability is one of the hallmarks of cancer commonly observed in patients with CRC, especially those with worse outcomes. The gain of whole chromosomes and structural aberrations involving one or different regions of the genome has been used over the years to explain the CRC evolution from carcinoma to metastatic CRC. ${ }^{[26]}$ At the molecular level, the genomic instability assessment seems to be a valuable tool to interrogate patients who might benefit from specific therapies.

Chromosomal instability (CIN): over $80 \%$ of all CRC cases display $\mathrm{CIN}$, the most common type of genomic aberration in this tumor. ${ }^{[27]} \mathrm{CIN}$ is mainly defined by the presence of aneuploidy or polyploidy, which is typically assessed by flow cytometry. The mechanisms underlying this genomic instability in CRC progression remain unclear; however, CIN is frequently associated with worse prognosis, therapy resistance, and poor survival. ${ }^{[28,29]}$

Microsatellite instability (MSI): it can be determined using molecular biology approaches based on amplification (e.g.: PCR) or immunohistochemistry. The immunohistochemistry method uses antibodies against mismatch repair (MMR) proteins (MLH1, MSH2, MSH6, and PMS2). If all proteins are present, the tumor is considered MMR proficient. Otherwise, the tumor is MMR deficient (dMMR), which is correlated with the presence of microsatellite instability. ${ }^{[30]}$ CRC is divided into MSI-high (MSI-H) or MSI-low (MSI-L), depending on the number of unstable markers identified by PCR. Tumors not classified as MSI-H or MSI-L are called stable microsatellites (MSS). ${ }^{[31]}$ Somatic defects in MMR genes have been reported in approximately $19 \%$ of CRC, while $52 \%$ showed hypermethylation in $\mathrm{MLH1}$ gene promoter, which is associated with gene inactivation. ${ }^{[32,33]}$ Therefore, if $\mathrm{dMMR}$ is detected by immunohistochemistry, it should prompt the evaluation of genes involved in the Lynch syndrome. Mutations in MMR genes are observed in patients with Lynch syndrome, also known as hereditary nonpolyposis colorectal cancer (HNPCC) syndrome, the most common cause of hereditary CRC. ${ }^{[34]}$

In general, MSI-H patients have no benefit from 5-FU treatment after surgery. Instead, these patients demonstrate lower survival than those who undergo surgery alone. ${ }^{[35]}$ Likewise, results from a retrospective study of adjuvant treatment showed that tumors with dMMR displayed poor results with adjuvant therapy with 5-FU in stage II, but not in stage III. ${ }^{36]}$ Results obtained from analysis of ACCENT database, with compilation of 12 randomized clinical trials, suggest that adding oxaliplatin to adjuvant fluoropyrimidine improves OS in patients with MSI stage III, and then it could be the standard-of-care adjuvant treatment for patients with CRC MSI/dMMR stage III. ${ }^{[37]}$ PETACC-3 study pointed out that tumors characterized by MSI-H are more frequently in stage II than III (22\% versus $12 \%$, respectively) and only $3 \%$ of patients with stage IV. These results suggest 
that tumors with MSI-H/dMMR still have little chance of metastasis. Favorable outcome was observed in those MSI-H. ${ }^{[38-40]}$ In summary, MSI predicts good outcome in $\mathrm{CRC}$, but it has no benefit to the treatment with fluoropyrimidine (5-FU). ${ }^{[41]}$ Therefore, the MSI evaluation using immunohistochemistry or molecular biology techniques-based is important to select patients at stages III and IV to adjuvant chemotherapy. ${ }^{[42]}$

CRC is commonly affected by tumor-infiltrating lymphocytes (TILs). ${ }^{[43]}$ Although the expression of immune checkpoints (PD-1, CTLA-4, and their ligands) is variable across the samples, higher expressions of PD-1 and PD-L1 correlates with better prognosis in CRC patients. ${ }^{[44]}$ Furthermore, MSI-H/dMMR patients display a high-density of T helper 1 (TH1) CD4+ cells, important to promote anti-tumor response, associated with upregulation of immune checkpoint. ${ }^{[4]}$ This fact could, at least in part, explain the low response ratio observed in the first clinical trials dedicated to investigating immune checkpoint inhibitors in unselected CRC patients. In 2015, it was shown the first evidence that only CRC MSI- H/dMMR patients would benefit from anti-PD-1 inhibitor (pembrolizumab) due to the incredible progression-free (PFS) and longterm OS reached upon treatment. ${ }^{[46]}$ Subsequent studies reinforced these findings exploring other anti-PD-1 inhibitors solely or associated with CTLA-4 inhibitors, ${ }^{[47]}$ accelerating their approval by the FDA in 2017. Finally, the phase III trial, KEYNOTE-177, showed an improvement in progression-free survival (16.5 months vs. 8.2 months; hazard ratio=0.60; 95\%Cl: 0.45-0.80; $p=0.0002$ ) for patients with MSI- H/ dMMR who received pembrolizumab versus chemotherapy in the first line $\mathrm{MCRC}$ setting. ${ }^{[48]}$

Loss of heterozygosity on chromosome $18 q(18 q \mathrm{LOH})$ : despite CIN and MSI, CRC might also harbor punctual chromosomal abnormalities. Loss of heterozygosity $(\mathrm{LOH})$ on chromosome $18 \mathrm{q}(18 \mathrm{qLOH})$ is the most frequent cytogenetic alteration in CRC, corresponding to $70 \%$ of cases, approximately. ${ }^{[49]}$ Patients with $18 \mathrm{qLOH}$ have worse prognosis likely due to its association with $\mathrm{CIN}$; ${ }^{[50]}$ however, it is still unclear whether $18 \mathrm{qLOH}$ represents an independent prognostic biomarker.

Fusion genes: fusion genes arising from chromosomal rearrangements contribute to the hallmarks of CRC, even being infrequent. Several fusion genes were reported, mostly involving actionable genes, such as NTRK, ALK, BRAF, RET, and FGFR. However, there is no still evidence of benefits for those patients upon treatment with tyrosine kinase inhibitors (TKI), but patients harboring NTRK- treated with entrectinib and larotrectinib. ${ }^{[51,52]}$ NTRK- fusions are associated with MSI-H, RAS and BRAF wild type (WT), dismal prognosis, and seems to explain part of the cases with primary resistance to EGFR therapy. ${ }^{[53,54]}$ Other fusion genes do not show impact on outcome or even correlation with disease subtype.

\section{Genetic mutations and aberrant expression}

The presence of mutations in genes implicated to cell signaling pathways that control proliferation, dif- ferentiation, apoptosis, angiogenesis, and invasion is as crucial as genomic instability for the pathogenesis of CRC. The most common pathways dysregulated in CRC are WNT- $\beta$-catenin, $\beta$ growth factor (TGF $\beta$ ), epidermal growth factor receptor via mitogen-activated protein kinases (EGFR-MAPK), and phosphatidylinositol 3-kinase (PI3K) signaling pathway (Figure 1). ${ }^{[55,56]}$

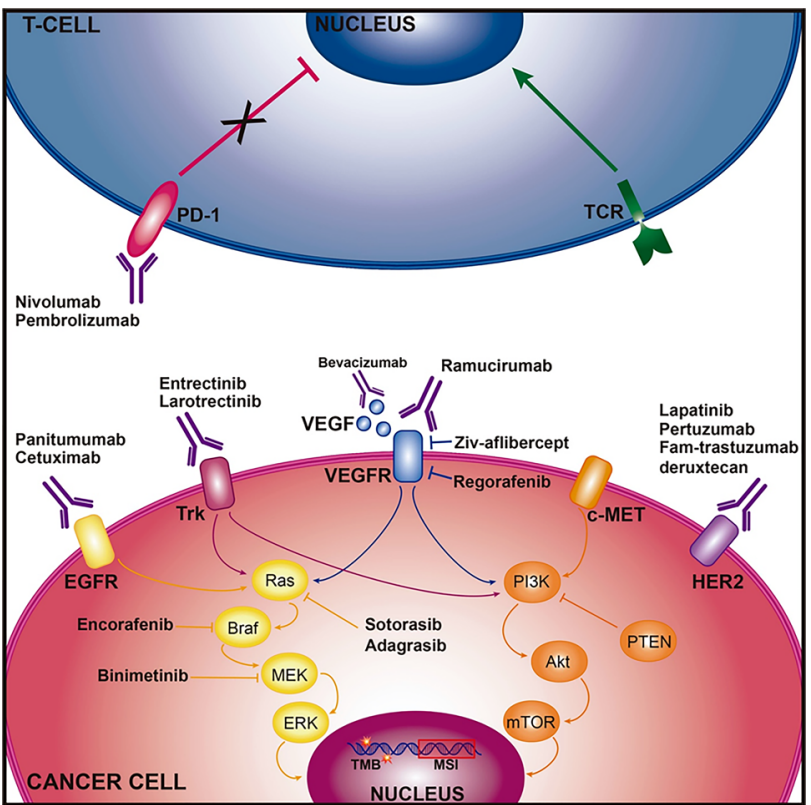

Figure 1. Biomarkers, signaling pathways and drugs in CRC. Genetic alterations frequently observed in CRC affect mainly signaling pathway receptors and their downstream partners. The target therapies already in clinical use can act on these biomarkers or immune cells, blocking checkpoint inhibitors to suppress T-cell response.

PI3KCA and PTEN: mutations in PI3KCA are observed in about $40 \%$ of CRC cases. In PTEN, a tumor suppressor gene that negatively regulates PI3K signaling, the mutations are present in about 30\% of MSI and 9\% of CIN tumors. ${ }^{[56]}$ The PI3K pathway is modulated by EGFR and through KRAS activation, but there is no evidence about the role of PIK3CA or PTEN mutations as predictive markers of anti-EGFR therapy. ${ }^{[57,58]} \mathrm{Mu}$ tations in those genes seem not to have an impact as prognostic biomarkers in CRC. ${ }^{[59,60]}$

KRAS and NRAS: KRAS mutations in codons 12 and 13 (exon 2) induce activation of MAPK/ERK cell signaling pathway regardless of the binding of growth factor to the cell surface receptor (e.g.: EGFR). ${ }^{[61,62]}$ These somatic variants can predict the lack of drug- response to cetuximab and panitumumab, both anti-EGFR therapy, and are present in about $40 \%$ of individuals with CRC. ${ }^{[63,64]}$ In Brazil, a cohort study analyzed over eight thousand patients with $\mathrm{MCRC}$ with average age of 59 years-old. ${ }^{[65]}$ In the study, authors performed KRAS genetic sequencing of codons 12 and 13 and revealed $31.9 \%$ of mutated cases. The PRIME study reported that $17 \%$ of 641 CRC patients did not present KRAS mutation in exon 2, but instead in exon 3 and 4, or in NRAS (exon 2-4). The authors concluded that patients with any KRAS or NRAS mutation who received anti-EGFR therapy did not have better rates 
of PFS and OS compared to those who received only chemotherapy. ${ }^{[64]}$ In addition, the presence of KRAS mutations do not correlate with age. ${ }^{[66]}$ Otherwise, the FIRE-3 trial included patients with KRAS (exon 2) codon 12/13 wild-type mCRC and displayed longer overall survival in patients who received FOLFIRI plus cetuximab compared to FOLFIRI plus bevacizumab. ${ }^{[67]}$ Currently, all CRC patients with stage IV are strongly suggested to be evaluated for -RAS and BRAF mutations to be treated with an anti-EGFR drug, as long as the tumor is not located in the right colon, given those patients do not benefit from that therapy at first-line regardless -RAS status. Recently, sotorasib and adagrasib showed efficacy in heavily pre-treated advanced solid tumors harboring the KRAS G12C mutation. Of the 42 patients with mCRC treated with sotorasib, 73.8\% (31 patients) had disease control and $7.1 \%$ (3 patients) had an objective response; the median progression-free survival was 4.0 months. ${ }^{[68]}$ Likewise, adagrasib showed acceptable safety profile and promising clinical activity in a small cohort of pre-treated mCRC patients with KRAS G12C mutation. ${ }^{[69]}$ Interesting, CRC patients that developed lung metastasis harbor KRAS mutations more frequently suggesting the screening for those alterations might be a relevant to lead patients to surgical resection. ${ }^{[70]}$

BRAF: approximately 5-9\% of the cases are characterized by a specific point mutation in BRAF (V600E), mutually exclusive with KRAS exon 2 variants. ${ }^{[71]}$ It is clear that $B R A F \mathrm{~V} 600 \mathrm{E}$ mutation is a strong prognostic factor. However, about $1 / 5$ of CRC patients with BRAF mutations harbor another different type than not V600E, in general, associated with younger men individuals with low-grade tumor. Also, the non-V600EBRAF were related to longer survival in those cases. ${ }^{[72]}$ Despite the strong correlation between the presence of BRAF mutations and MSI, these alterations might also affect MSS patients and correlate with lower survival, whereas no impact is observed in MSI cases. ${ }^{[73]}$ The PETACC-3 study demonstrated that mutations in this gene were strong predictors of poor OS in patients with MSI-L/MSS in stage II or III, being these data confirmed by CRYSTAL and AGITG MAX trials. ${ }^{[74-76]}$ The evaluation of CRC refractory to chemotherapy suggested that BRAF mutations display significantly lower response rate to cetuximab than WT tumors (8.3\% vs. 38.0\%). ${ }^{[77]}$ Additionally, patients with BRAF V600E-mutated $\mathrm{mCRC}$ who had disease progression after one or two previous regimens had a longer OS with the combination of encorafenib, binimetinib, and cetuximab or encorafenib and cetuximab compared to the control group (cetuximab plus irinotecan or cetuximab plus FOLFIRI). ${ }^{[78]}$

Vascular endothelial growth factor (VEGF): although VEGF and its receptor can be targeted by monoclonal antibodies (MoAb), their role as a predictive biomarker is not established. Bevacizumab (MoAb targeting VEGF-A) has shown improvements in PFS and OS in the first- and second-line treatment of mCRC when combined to fluoropyrimidine-based chemotherapy backbone. ${ }^{[79-81]}$ Moreover, ramucirumab (MoAB that binds to VEGFR-2) and aflibercept (recombinant fusion protein that binds VEGF-A, VEGF-B and placental growth factor) has shown improvements in PFS and OS when added to fluoropyrimidine-based chemotherapy backbone in the second-line treatment of mCRC. ${ }^{[82,83]}$

SMAD4: in 2012, Isaksson-Mettävainio et al. ${ }^{[84]}$ showed that high expression of SMAD4 was significantly correlated with a favorable prognosis in CRC $\mathrm{MSI}-\mathrm{H}$. Previous studies have revealed that loss of SMAD4 expression was associated with advanced stage, metastatic potential, adverse prognosis, and $18 \mathrm{qLOH}$, regardless of MSI status. ${ }^{[85]}$ However, the underlying mechanism and prognostic value of variations in SMAD4 expression in CRC are not completely elucidated.

HER-2: ERBB2 oncogene amplification or HER2 protein overexpression accounts for 3-5\% of CRC, but the frequency of alterations in the gene might increase after treatment with to anti- EGFR. ${ }^{[86]}$ Therefore, screening for such alterations through more sensitive and less invasive approaches after EFGR-therapy resistance might be a trend. Although alterations in MET e HER-2 seem to confer resistance to this type of therapy, some patients with HER2 ${ }^{a m p}$ can benefit from HER-2 inhibitor. ${ }^{\left[{ }^{[7-90]}\right.}$ The phase II HERACLES trial showed that the combination of trastuzumab and lapatinib in 27 eligible patients with HER-2-overexpressing $\mathrm{mCRC}$ and KRAS exon 2 WT resulted in $30 \%$ objective response and $44 \%$ stable disease. ${ }^{[87]}$ Furthermore, MyPathway study showed 32\% objective response with trastuzumab plus pertuzumab in HER-2 overexpressed or amplified mCRC. ${ }^{[91]}$ Lately, the phase II DESTINY-CRC01 trial showed that the use of Fam-trastuzumab deruxtecan resulted in 45\% objective response rate in pre- treated HER-2-overexpressing mCRC patients with a median PFS of 6.9 months and duration of response not reached. ${ }^{[92]}$

POLE and POLD1: polymerase proofreading-associated polyposis is a dominant-inheritance and high-penetrance hereditary syndrome, caused by variants in the exonuclease domain (EDMs) in POLE and POLD1 genes, and it is correlated with a predisposition to attenuated colorectal polyposis and early-onset CRC. POLE mutations have been reported in approximately $2 \%$ of patients and were related to better outcomes in stage II-III CRC. ${ }^{[93]}$ Domingo et al. (2016) ${ }^{[94]}$ also reported upregulation of immune checkpoints in patients with POLE EDMs. These findings further suggested that CRC patients with these mutations might respond to immune checkpoint inhibitors when clinically indicated their administration. ${ }^{\text {[95] }}$

$P D-L 1$ : most of these genetic variants cannot predict response to immunotherapy, which in many cases can be associated with PD-L1 expression. PD-1 is a cell surface receptor expressed by activated T-cells, $\beta$ lymphocytes, natural killer cells and myeloid-derived suppressor cells. ${ }^{[96]}$ PD-L1 is a cell surface receptor expressed in tumor cells. PD-1 and PD-L1 inhibitors can revert the immunotolerance state caused by the tumor. A recent 
study suggested that PD-L1 expression has a broader role as a potential biomarker for predicting response to immune treatment. ${ }^{[97]}$ PD-L1 expression was significantly correlated with lymphatic metastasis, tumor diameter and differentiation, vascular invasion, and could act as an independent poor prognostic factor in CRC. ${ }^{[98]}$ Nonetheless, the correlation between PD-L1 expression and clinicopathological features and prognosis of CRC is still controversial.

\section{Molecular subtypes of CRC - International CRC Subtyping Consortium Classification}

Like other solid tumors, it is unfeasible to define CRC stratification at the molecular level only by one mutation or just a few events. The classification of patients into robust clinically defined subsets requires the combination of multiple biomarkers using different approaches, such as mutational evaluation, gene expression, and protein analysis, through a comprehensive assessment (Table 1).

It has been shown over the years the impact of epigenetics impairment on leukemia and solid tumors. [99] The disbalance in gene expression of key regulators implicated in proliferation, apoptosis and other cancer hallmarks can be explained beyond chromosomal damage, copy number alterations (CNA) and point mutations, as discussed so far. Epigenome mainly affects gene expression regulation and can act on different levels - DNA methylation, histone modifications and non-coding RNAs.

The International Colorectal Cancer Subtyping Consortium classified CRC patients into four different groups based on the tumor gene expression profile: CMS1 (MSI, immune), CMS2 (canonical), CMS3 (metabolic), and CMS4 (mesenchymal). ${ }^{[100]}$ All groups show distinct outcome and seem to exhibit a specific mutational pattern.

CMS1 group represents about 14\% of all CRC cases; it has low prevalence of somatic CNA and is generally hypermethylated. These tumors show abundant immune infiltrate and are associated with MSI. Interestingly, CMS1 shows overactivation of JAK/STAT pathway, which seems to be related to the upregulation of proteins involved in immune response and enrichment of cases with BRAF V600 mutation. Besides the molecular landscape, CMS phenotypes can display a correlation with tumor location and histopathological features. For instance, most of the CMS1 tumors are observed in women with right-sided lesions and high histopathological grade. Compared to the other groups, CMS1 patients hold favorable outcome, which could be explained by the high diffuse immune infiltrate, mainly compounded by cytotoxic cells. ${ }^{[101]}$

The canonical (CMS2) and mesenchymal (CMS4) phenotypes are characterized by $\mathrm{CNI}$, which was initially measured through high levels of CNA. On the other hand, the distribution of nonsynonymous somatic mutation events is not high in those cases. CNI, commonly observed in CMS2 tumors, is the main reason to explain why over $1 / 3$ of all CRC patients are classified into this subset, thus being named canonical subtype. APC mutations/loss are enriched in CMS2 tumors, as well as somatic variants in KRAS, and activation of Wnt/c-Myc, which is consistent with an

Table 1. Surrogate biomarkers in CRC and their clinical features.

\begin{tabular}{|c|c|c|c|}
\hline Biomarker & Alteration & Clinical Implication & References \\
\hline CIN & Aneuploidy and polyploidy & Poor prognosis & $(28)$ \\
\hline MSI / dMMR & Amplification / deficient MMR & Good prognosis; increased RFS & $(37-39)$ \\
\hline $18 q \mathrm{LOH}$ & $\begin{array}{c}\text { proteins } \\
\text { Loss of heterozygosity on }\end{array}$ & $\begin{array}{c}\text { Response to immunotherapy; in- } \\
\text { creased PFS } \\
\text { Poor prognosis }\end{array}$ & $\begin{array}{l}(46,47) \\
(49)\end{array}$ \\
\hline NTRK & $\begin{array}{l}\text { chromosome } 18 q \\
\text { Fusion }\end{array}$ & Poor prognosis & $(50-53)$ \\
\hline \multirow[t]{2}{*}{ KRAS } & Mutation & $\begin{array}{c}\text { Response to TKI } \\
\text { Resistance to anti-EGFR therapy }\end{array}$ & $(62)$ \\
\hline & & Response to TKI & $(64,65)$ \\
\hline \multirow[t]{3}{*}{ BRAF } & Mutation & Poor prognosis & $(67,69)$ \\
\hline & & Resistance to anti-EGFR therapy & $(70)$ \\
\hline & & Response to TKI & (71) \\
\hline MET & Overexpression & Resistance to anti-EGFR therapy & $(81)$ \\
\hline \multirow[t]{2}{*}{ HER2 } & Amplification or & Resistance to anti-EGFR therapy & (83) \\
\hline & overexpression & Response to anti-HER2 therapy & $(80,82,84,85)$ \\
\hline ctDNA & Mutation & Predictive of recurrence & $(107)$ \\
\hline TMB & Mutation (/per Mb) & Response to immunotherapy & (113) \\
\hline
\end{tabular}

Abbreviations: CIN: Chromosomal instability; MSI: Microsatellite instability; dMMR: Deficient mismatch repair proteins; RFS: Relapse-free survival; PFS: Progression-free survival; EGFR: Epidermal growth factor receptor; TKI: Tyrosine kinase inhibitor; cfDNA: Circulating tumor DNA; TMB: Tumor mutational burden; Mb: Megabase. 
upregulation of its downstream targets. Conversely observed in CMS1, CMS2 tumors are mainly left-sided and display superior survival rates after relapse. Regarding the morphological appearance, CMS2 and CMS3 are more epithelial-like (tubular adenoma), whereas CMS1 and CMS4 are mesenchymal. ${ }^{[102]}$

CMS3 and CMS4 represent 13\% and 23\% of CRC cases, respectively, having CMS4 the worst prognosis across all molecular subtypes. ${ }^{[100]}$ Such as CMS2, CMS3 display features of epithelial-like characteristics, as well as metabolic dysregulation, with mixed MSI and ubiquitous MAPK pathway alterations, marked by mutations in KRAS gene. As previously discussed, CRC is characterized by genome instability commonly arising from dMMR and global genome hypermethylation, resulting in CPG island methylator phenotype (CIMP). ${ }^{[103]}$ Despite its strong association with MSI, presence of mucinous features, poor tumor differentiation, and mutations in BRAF, CIMP is enriched in CMS1 and underrepresented in CMS3. On the other hand, CMS4 group characterized by CIN showed upregulation of genes implicated to angiogenesis, matrix remodeling, and epithelial-mesenchymal transition pathways, which in part respond why most $\mathrm{MCRC}$ cases are found in this molecular subtype. Notwithstanding the poor prognosis, only CMS4 patients seem to benefit from cetuximab, although with reduced sensitivity to chemotherapy. ${ }^{[104,105]}$

\section{NOVEL APPROACHES}

Circulating tumor DNA: for many years, clinicians and researchers pursued reliable strategies to access tumoral genetic and epigenetic features using non-invasive techniques. Regardless of underlying conditions, individuals can carry DNA in the blood, generally fragments not larger than 200kb. ${ }^{[106]}$ This circulating cell-free DNA (cfDNA) seems to be more abundant in cancer patients (circulating cell-free tumor DNA ctDNA) than in healthy individuals or subjects with non-malignant conditions. These molecules have been studied as surrogate markers in diagnosis establishment, prognosis assessment, predict treatment response, but mainly to monitor minimum residual disease (MRD). ${ }^{[106-109]}$ A strong correlation between ctDNA and anatomical site of CRC was reported. In summary, patients with colon tumors tend to exhibit higher amounts of ctDNA in plasma than individuals with rectum tumors, ${ }^{[110]}$ although this is not a consensus. Most of the studies investigating ctDNA in CRC context screened mutations previously identified in the tumor site to determine whether the findings obtained from liquid biopsy are reliable and can translate faithfully the genetic landscape of the tumor. Mutations in BRAF and KRAS genes had $>95 \%$ of concordance between tumor and ctDNA analysis, especially in patients with advanced disease. ${ }^{[111,112]}$ In addition, those variants were successfully tracked in plasma following tumor evolution, endorsing that this is a promising approach to be used instead of tumor-section investigation. ${ }^{[13]}$ The identification of fusion genes and other actionable genes were reported also. ${ }^{[14]}$ There is a dramatic drop in the levels of plasmatic ctDNA in patients subjected to surgery or other therapies, but it is still possible to detect it over time. In 2019, Reinert et al. ${ }^{[115]}$ proposed that longitudinal investigation of ctDNA presence in samples from postoperative patients would be able to predict relapse up to 16 months earlier. Liquid biopsy is being used also to track the clonal dynamics of malignant cells after anti-EGFR therapy in CRC. ${ }^{[116]}$ Mutations in RAS and EGFR showed relative allele frequency decays after therapy with a cumulative halflife of 4.4 months. Interesting, ctDNA monitoring was useful to guide the timing of re-challenge therapies for those patients, guiding them to higher responses. The Colon and Rectal-Anal Task Forces of the United States National Cancer Institute has been discussing how ctDNA might improve the clinical management of CRC by the detection of MRD and monitoring responses to therapy. ${ }^{[117]}$

Tumor mutational burden (TMB): the comprehensive tumoral investigation to discovery new biomarkers is going beyond the mutational landscape and gene expression signatures. Most exploratory studies with satisfactory response upon immunotherapeutic agents were performed on solid tumors, such as melanoma, non-small-cell lung carcinoma, advanced renal cell carcinoma, and CRC. ${ }^{[18]}$ Levels of PD-1 and CTLA-4 expression, immune landscape (tumor-infiltrating immune cells profiling), and TMB have been mostly used to explain clinical response and predict which are the cases that will benefit from these immune checkpoint inhibitors. TMB is defined as the number of somatic variants found across the DNA of cancer cells and based on that, it is classified into hypermutated (TMB high) or non-hypermutated (TMB low). TMB and POLE mutations have been associated with clinical outcomes becoming promising biomarkers for both predictive and prognostic value in diverse cancers, including CRC. Studies have shown that besides patients with MSI-H tumors, CRC patients with MSS tumors and high TMB may respond to immunotherapy. ${ }^{[119,120]}$ In MSI-H mCRC TMB is likely an independent biomarker and recent studies associated TMB with more favorable prognosis in CRC patients treated with chemotherapy and targeted therapy. ${ }^{[121]}$ Also, there is no universal definition of high TMB considering that cut-points associated with improved survival between cancer types is varied. [122] The data from KEYNOTE-158, a phase II clinical trial study in multiple cancer types investigating the efficacy and safety of pembrolizumab, demonstrated that high TMB was associated with higher ORR $(28.3 \%$ vs. $6.5 \%)$ in patients with select advanced solid tumors treated with pembrolizumab monotherapy, which accelerated the pembrolizumab's agnostic approval by FDA in patients with high TMB. ${ }^{[123]} \mathrm{How}$ ever, there was no CRC patients included in this trial.

Microbiome: the whole community of microorganisms living within a particular individual is defined as 
microbiome. These microbes habit and interact actively with different body tissues, such as skin, gut, and stomach, and drive a remarkable role in immune cells ontogeny. There is no direct evidence that the commensal microbiome plays a determinant role in cancer pathogenesis, even though it has been shown its cooperation on tumor initiation and progression. ${ }^{[124]}$ Intriguingly, patients with metastatic melanoma responsive to PD-1/PD-L1 axis inhibition seem to have differences in the gut microbiota composition compared to unresponsive cases. ${ }^{[125,126]}$ In CRC, Fusobacterium nucleatum modulates the expression of genes implicated in immune cells recruitment leading to poor T-cell infiltration, which could explain at some point the differences observed in the profile of immunotherapy response. ${ }^{[127,128]}$ In general, cancerous and normal tissue's overall microbiome is very similar. In contrast, CRC patients display more Lactobacillales and reduced Faecalibacterium than healthy individuals. ${ }^{[129]}$ These differences are also observed in the CRC virome (whole viral composition), which could explain in part the bacterial composition of these tissues, given that viruses such as Inovirus and Tunalikevirus are enriched in CRC patients and can infect gram- negative bacteria. ${ }^{[11]}$ Most of the studies in microbiome field only observed a correlation between microbiological composition in a given tumor. Although it is not totally understood how the microbiome influences cancer pathogenesis and progression, in vivo experiments suggest those bacterias promote inflammation and metabolic changes leading normal cells toward malignant phenotype or even cancer progression. ${ }^{[130]}$

More recently, studies have identified the relationship between certain strains of Escherichia coli with a pathogenic island, named pks+ Escherichia coli, which is attributed to polyketide synthetases (pks) that produces the genotoxin colibactin. This colibactin-producing bacteria promotes DNA damage, across interstrand crosslinks and double-strand breaks in cultured cells, with pro-tumorigenic effect. Using organoid technology, Pleguezuelos-Manzano et al. (2020) ${ }^{[131]}$ identified two unique mutational signatures (single base substitution named SBS-pks and small insertion and deletion, the ID-pks) caused by exposure to $p k s+E$. coli. Those signatures were correlated with colorectal metastases and primary tumors through two WGS datasets. The first analysis of data was from a Dutch collection of 3,668 solid cancer metastases (496 from CRC) revealed that 7.5\% of CRC samples were enriched for SBS-pks and 8.8\% for ID-pks, while the second analysis of the Genomics England 100,000 Genomes Project with 2,208 CRC tumours, confirmed the fingerprint of SBS and ID-pks in $5 \%$ and $4.4 \%$ of patients, respectively. Furthermore, the researchers also analyzed seven cohorts of patients with colorectal cancer and their driver mutations, defining $p k s$ signatures as oncogenic mutations, once they were observed in $2.4 \%$ of 4,712 CRC drivers mutations, and associated with mutations in APC gene, which harbored the highest number of mutations containing these signatures (5.3\%). ${ }^{[131]}$ In 2019, Lee-Six et al..132] identified two mutational signatures occurring in healthy colonic crypts named as SBS-A and ID-A in 29 of 42 individuals, and data analysis suggest that these signatures were acquired in children before 10 years of age. These signatures were confirmed by Pleguezuelos-Manzano et al. $(2020)^{[131]}$ with the same aetiology of SBS-pks and ID-pks. Although more investigation is needed, researchers highlights about the colibactin mutagenic effect in vitro, the mutational signatures associated with a risk of developing CRC and promotes discussion about re-evaluation of probiotics that contain genotoxic strains of $E$. coli. ${ }^{[131]}$

\section{CONCLUSION}

Over the last decades, the molecular mechanisms of CRC carcinogenesis have been unraveled. The identification of signaling pathways committed to CRC, as well as their genetic vulnerabilities, allowed the establishment of new biomarkers, druggable targets, and therapeutic agents. These new findings resulted from the development of genomic high-throughput approaches, such as next-generation sequencing and array-based techniques. New biomarkers in CRC range from chromosomal changes to specific variations in the DNA sequence, and when grouped, allow the establishment of clinically homogeneous groups with a well-defined prognosis and treatment.

Most of these markers are already being used in clinical practice, and many others will be inserted into the routine as soon as possible. In precision medicine, the biggest challenge will be the development of algorithms that combine these new findings to efficiently predict each patient's response profile to the respective drugs.

\section{FUNDING INFORMATION}

This work was supported by Instituto COI.

\section{AUTHOR CONTRIBUTIONS}

Conceptualization: J.C, A.P.V, L.H.A and F.M.A.C.V. Writing-original draft preparation: J.C, A.P.V and F.M.A.C.V.

Writing-review and editing: J.C, A.P.V, K.B.A, L.H.A and F.M.A.C.V.

All authors have read and agreed to the final version of the manuscript.

\section{CONFLICT OF INTEREST STATEMENT}

The authors declare no conflicts of interest.

\section{REFERENCES}

1. International Agency for Research on Cancer (IARC); World Health Organization (WHO). Global cancer observatory (GCO) [Internet]. Geneva: IARC/WHO; 2020; [access in 2020 Sep 22]. Available from: https://gco.iarc.fr 
2. National Cancer Institute (NIH). Cancer stat facts: colorectal cancer [Internet]. Bethesda: NIH; 2020; [access in 2020 May 17]. Available from: https://seer.cancer.gov/statfacts/html/colorect. html

3. Kocarnik JM, Shiovitz S, Phipps Al. Molecular phenotypes of colorectal cancer and potential clinical applications. Gastroenterol Rep (Oxf). 2015;3(4):269-76. DOI: https://doi.org/10.1093/ gastro/gov046

4. Loree JM, Pereira AAL, Lam M, Willauer AN, Raghav K, Dasari A, et al. Classifying colorectal cancer by tumor location rather than sidedness highlights a continuum in mutation profiles and consensus molecular subtypes. Clin Cancer Res. 2018 Mar;24(5):1062-72. DOI: https://doi. org/10.1158/1078-0432.CCR-17-2484

5. Wong R. Proximal tumors are associated with greater mortality in colon cancer. J Gen Intern Med. 2010 Jul;25:1157-63. DOI: https://doi. org/10.1007/s11606-010-1460-4

6. Missiaglia E, Jacobs B, D'Ario G, Di Narzo AF, Soneson C, Budinska E, et al. Distal and proximal colon cancers differ in terms of molecular, pathological, and clinical features. Ann Oncol. 2014 Oct;25(10):1995-2001. DOI: https://doi. org/10.1093/annonc/mdu275

7. Wang CB, Shahjehan F, Merchea A, Li Z, BekaiiSaab TS, Grothey A, et al. Impact of tumor location and variables associated with overall survival in patients with colorectal cancer: a Mayo clinic colon and rectal cancer registry study. Front Oncol. 2019;9:76. DOI: https://doi.org/10.3389/ fonc.2019.00076

8. Wang B, Yang J, Li S, Lv M, Chen Z, Li E, et al. Tumor location as a novel high risk parameter for stage II colorectal cancers. PLoS One. 2017;12(6):e0179910. DOI: https://doi. org/10.1371/journal.pone.0179910

9. Warschkow R, Sulz MC, Marti L, Tarantino I, Schmied BM, Cerny T, et al. Better survival in right-sided versus left-sided stage I - III colon cancer patients. BMC Cancer. 2016 Jul;16:554. DOI: https://doi.org/10.1186/s12885-016-2412-0

10. Yamashita S, Brudvik KW, Kopetz SE, Maru D, Clarke CN, Passot G, et al. Embryonic origin of primary colon cancer predicts pathologic response and survival in patients undergoing resection for colon cancer liver metastases. Ann Surg. 2018 Mar;267(3):514-20. DOI: https://doi. org/10.1097/SLA.0000000000002087

11. Sanchez-Alcoholado $L$, Ramos-Molina $B$, Otero A, Laborda-Illanes A, Ordonez R, Medina JA, et al. The role of the gut microbiome in colorectal cancer development and therapy response. Cancers (Basel). 2020;12(6):1406. DOI: https://doi. org/10.3390/cancers12061406
12. Dahmus JD, Kotler DL, Kastenberg DM, Kistler $\mathrm{CA}$. The gut microbiome and colorectal cancer: a review of bacterial pathogenesis. J Gastrointest Oncol. 2018;9(4):769-77. DOI: https://doi. org/10.21037/jgo.2018.04.07

13. Verhulst J, Ferdinande L, Demetter $P$, Ceelen W. Mucinous subtype as prognostic factor in colorectal cancer: a systematic review and meta-analysis. J Clin Pathol. 2012;65(5):381-8. DOI: https://doi.org/10.1136/jclinpath-2011-200340

14. Hugen N, Van de Velde CJH, Wilt JHW, Nagtegaal ID. Metastatic pattern in colorectal cancer is strongly influenced by histological subtype. Ann Oncol. 2014;25:651-7. DOI: https://doi. org/10.1093/annonc/mdt591

15. Maisano R, Azzarello D, Maisano M, Mafodda A, Bottari M, Egitto G, et al. Mucinous histology of colon cancer predicts poor outcomes with FOLFOX regimen in metastatic colon cancer. J Chemother. 2012 Aug;24(4):212-6.

16. McCawley N, Clancy C, O'Neill BD, Deasy J, McNamara DA, Burke JP. Mucinous rectal adenocarcinoma is associated with a poor response to neoadjuvant chemoradiotherapy: a systematic review and meta-analysis. Dis Colon Rectum. 2016 Dec;59(12):1200-8. DOI: https://doi. org/10.1097/DCR.0000000000000635

17. Thota R, Fang X, Subbiah S. Clinicopathological features and survival outcomes of primary signet ring cell and mucinous adenocarcinoma of colon: retrospective analysis of VACCR database. J Gastrointest Oncol. 2014 Feb;5(1):18-24.

18. Yun SO, Cho YB, Lee WY, Kim HC, Yun SH, Park $Y A$, et al. Clinical significance of signet-ring-cell colorectal cancer as a prognostic factor. Ann Coloproctol. 2017 Dec;33(6):232-8. DOI: https://doi. org/10.3393/ac.2017.33.6.232

19. Gao Y, Wang J, Zhou Y, Sheng S, Qian SY, Huo X. Evaluation of Serum CEA, CA19- 9, CA72-4, CA125 and ferritin as diagnostic markers and factors of clinical parameters for colorectal cancer. Sci Rep. 2018 Feb;8:2732. DOI: https://doi.org/10.1038/ s41598-018-21048-y

20. Huang CJ, Jiang JK, Chang SC, Lin JK, Yang SH. Serum CA125 concentration as a predictor of peritoneal dissemination of colorectal cancer in men and women. Medicine (Baltimore) 2016;95(47):e5177. DOI: https://doi.org/10.1097/MD.0000000000005177

21. Brouwer NPM, Bos A, Lemmens V, Tanis PJ, Hugen N, Nagtegaal ID, et al. An overview of 25 years of incidence, treatment and outcome of colorectal cancer patients. Int J Cancer. 2018 Aug;143(11):2758-66. DOI: https://doi. org/10.1002/ijc.31785

22. Messersmith WA. NCCN guidelines updates: management of metastatic colorectal cancer. J Natl Compr Canc Netw. 2019 May;17(5):599-601. 
23. Brown KGM, Solomon MJ, Mahon K, O'Shannassy S. Management of colorectal cancer. BMJ. 2019;366:I4561. DOI: https://doi.org/10.1136/ bmj.14561

24. Vogel A, Hofheinz RD, Kubicka S, Arnold D. Treatment decisions in metastatic colorectal cancer - Beyond first and second line combination therapies. Cancer Treat Rev. 2017 Sep;59:54-60. DOI: https://doi.org/10.1016/j.ctrv.2017.04.007

25. Xie YH, Chen YX, Fang JY. Comprehensive review of targeted therapy for colorectal cancer. Signal Transduct Target Ther. 2020;5:22. DOI: https:// doi.org/10.1038/s41392-020-0116-z

26. Fearon ER, Vogelstein B. A genetic model for colorectal tumorigenesis. Cell. 1990 Jun;61(5):759-67. DOI: https://doi.org/10.1016/0092-8674(90)90186-i

27. Grady WM, Carethers JM. Genomic and epigenetic instability in colorectal cancer pathogenesis. Gastroenterology. 2008 Oct;135(4):1079-99.

28. Walther A, Houlston R, Tomlinson I. Association between chromosomal instability and prognosis in colorectal cancer: a meta-analysis. Gut. 2008;57(7):94150. DOI: https://doi.org/10.1136/gut.2007.135004

29. Hoevenaar WHM, Janssen A, Quirindongo Al, Ma $H$, Klaasen SJ, Teixeira A, et al. Degree and site of chromosomal instability define its oncogenic potential. Nat Commun. 2020;11:1501. DOI: https://doi.org/10.1038/s41467-020-15279-9

30. Evrard C, Tachon G, Randrian V, Karayan-Tapon L, Tougeron D. Microsatellite instability: diagnosis, heterogeneity, discordance, and clinical impact in colorectal cancer. Cancers (Basel). 2019;11(10):1567. DOI: https://doi.org/10.3390/cancers11101567

31. Kim GP, Colangelo LH, Wieand HS, Paik S, Kirsch $\mathrm{IR}$, Wolmark N, et al. Prognostic and predictive roles of high-degree microsatellite instability in colon cancer: a National Cancer Institute-National Surgical Adjuvant Breast and Bowel Project Collaborative Study. J Clin Oncol. 2007;25(7):767-72. DOI: https://doi.org/10.1200/JCO.2006.05.8172

32. Halvarsson B, Anderson H, Domanska K, Lindmark G, Nilbert M. Clinicopathologic factors identify sporadic mismatch repair-defective colon cancers. Am J Clin Pathol. 2008;129(2):238-44. DOI: https://doi. org/10.1309/0PP5GDRTXUDVKAWJ

33. Cunningham JM, Christensen ER, Tester DJ, Kim CY, Roche PC, Burgart LJ, et al. Hypermethylation of the hMLH1 promoter in colon cancer with microsatellite instability. Cancer Res. 1998 Aug;58(15):3455-60.

34. Giardiello FM, Allen JI, Axilbund JE, Boland CR, Burke CA, Burt RW, et al. Guidelines on genetic evaluation and management of Lynch syndrome: a consensus statement by the US Multi-Society Task Force on colorectal cancer. Gastroenterology. 2014 Aug;147(2):502-26.
35. Ribic CM, Sargent DJ, Moore MJ, Thibodeau SN, French AJ, Goldberg RM, et al. Tumor microsatellite-instability status as a predictor of benefit from fluorouracil-based adjuvant chemotherapy for colon cancer. N Engl J Med. 2003 Jul;349:24757. DOI: https://doi.org/10.1056/NEJMoa022289

36. Sargent DJ, Marsoni S, Monges G, Thibodeau SN, Labianca R, Hamilton SR, et al. Defective mismatch repair as a predictive marker for lack of efficacy of fluorouracil-based adjuvant therapy in colon cancer. J Clin Oncol. 2010;28(20):3219-26. DOI: https://doi.org/10.1200/JCO.2009.27.1825

37. Cohen R, Taieb J, Fiskum J, Yothers G, Goldberg $\mathrm{R}$, Yoshino $\mathrm{T}$, et al. Microsatellite instability in patients with stage III colon cancer receiving fluoropyrimidine with or without oxaliplatin: an ACCENT pooled analysis of 12 adjuvant trials. J Clin Oncol. 2021;39(6):642-51. DOI: https://doi. org/10.1200/JCO.20.01600

38. Roth AD, Tejpar S, Delorenzi M, Yan P, Fiocca R, Klingbiel D, et al. Prognostic role of KRAS and BRAF in stage II and III resected colon cancer: results of the translational study on the PETACC-3, EORTC 40993, SAKK 60-00 trial. J Clin Oncol. 2010;28(3):46674. DOI: https://doi.org/10.1200/JCO.2009.23.3452

39. Koopman M, Kortman GA, Mekenkamp L, Ligtenberg MJ, Hoogerbrugge N, Antonini NF, et al. Deficient mismatch repair system in patients with sporadic advanced colorectal cancer. Br J Cancer. 2009;100:266-73. DOI: https://doi.org/10.1038/ sj.bjc. 6604867

40. Sinicrope FA, Mahoney MR, Smyrk TC, Thibodeau $\mathrm{SN}$, Warren RS, Bertagnolli MM, et al. Prognostic impact of deficient DNA mismatch repair in patients with stage III colon cancer from a randomized trial of FOLFOX-based adjuvant chemotherapy. J Clin Oncol. 2013;31(29):3664-72. DOI: https://doi.org/10.1200/JCO.2013.48.9591

41. Webber EM, Kauffman TL, O'Connor E, Goddard KA. Systematic review of the predictive effect of MSI status in colorectal cancer patients undergoing 5FUbased chemotherapy. BMC Cancer. 2015;15:156. DOI: https://doi.org/10.1186/s12885-015-1093-4

42. Shia J. Immunohistochemistry versus microsatellite instability testing for screening colorectal cancer patients at risk for hereditary nonpolyposis colorectal cancer syndrome. Part I. The utility of immunohistochemistry. J Mol Diagn. 2008;10(4):293-300.

43. B, Lagorce-Pages C, et al. Type, density, and location of immune cells within human colorectal tumors predict clinical outcome. Science. 2006;313(5795):1960-4. DOI: https://doi. org/10.1126/science.1129139

44. Li Y, Liang L, Dai W, Cai G, Xu Y, Li X, et al. Prognostic impact of programed cell death-1 (PD-1) and PD-ligand 1 (PD-L1) expression in cancer cells and tumor infiltrating lymphocytes in colorectal cancer. Mol Cancer. 2016 Aug;15:55. DOI: https://doi.org/10.1186/s12943-016-0539-x 
45. Llosa NJ, Cruise M, Tam A, Wicks EC, Hechenbleikner EM, Taube JM, et al. The vigorous immune microenvironment of microsatellite instable colon cancer is balanced by multiple counter-inhibitory checkpoints. Cancer Discov. 2015;5:43-51. DOI: https://doi.org/10.1158/2159-8290.CD-14-0863

46. Le DT, Uram JN, Wang H, Bartlett BR, Kemberling $H$, Eyring $A D$, et al. PD-1 blockade in tumors with mismatch-repair deficiency. N Engl J Med. 2015 Jun;372:2509-20. DOI: https://doi.org/10.1056/ NEJMoa1500596

47. Overman MJ, McDermott R, Leach JL, Lonardi S, Lenz $\mathrm{HJ}$, Morse MA, et al. Nivolumab in patients with metastatic DNA mismatch repair-deficient or microsatellite instability-high colorectal cancer (CheckMate 142): an open-label, multicentre, phase 2 study. Lancet Oncol. 2017 Sep;18(9):1182-91. DOI: https://doi.org/10.1016/S1470-2045(17)30422-9

48. André T, Shiu KK, Kim TW, Jensen BV, Jensen LH, Punt C, et al. Pembrolizumab in microsatellite-instability-high advanced colorectal cancer. N Engl J Med. 2020;383:2207-18. DOI: https://doi. org/10.1056/NEJMoa2017699

49. Vogelstein B, Fearon ER, Hamilton SR, Kern SE, Preisinger AC, Leppert $M$, et al. Genetic alterations during colorectal-tumor development. N Engl J Med. 1988 Sep;319:525-32. DOI: https:// doi.org/10.1056/NEJM198809013190901

50. Walther A, Johnstone E, Swanton C, Midgley R, Tomlinson I, Kerr D. Genetic prognostic and predictive markers in colorectal cancer. Nat Rev Cancer. 2009;9:489-99. DOI: https://doi.org/10.1038/ nrc2645

51. Drilon A, Laetsch TW, Kummar S, DuBois SG, Lassen UN, Demetri GD, et al. Efficacy of larotrectinib in TRK fusion-positive cancers in adults and children. N Engl J Med. 2018;378:731-9. DOI: https://doi.org/10.1056/NEJMoa1714448

52. Doebele RC, Drilon A, Paz-Ares L, Siena S, Shaw AT, Farago AF, etal. Entrectinib in patientswith advanced or metastatic NTRK fusion-positive solid tumours: integrated analysis of three phase 1\&\#x2013;2 trials. Lancet Oncol. 2020 Feb;21(2):271-82. DOI: https://doi.org/10.1016/S1470-2045(19)30691-6

53. Pietrantonio F, Di Nicolantonio F, Schrock AB, Lee J, Tejpar S, Sartore-Bianchi A, et al. ALK, ROS1, and NTRK rearrangements in metastatic colorectal cancer. J Natl Cancer Inst. 2017;109:djx089. DOI: https://doi.org/10.1093/jnci/djx089

54. Pagani F, Randon G, Guarini V, Raimondi A, Prisciandaro $M$, Lobefaro $R$, et al. The landscape of actionable gene fusions in colorectal cancer. Int J Mol Sci. 2019;20. DOI: https://doi. org/10.3390/ijms20215319

55. Siena S, Sartore-Bianchi A, Di Nicolantonio F, Balfour J, Bardelli A. Biomarkers predicting clinical outcome of epidermal growth factor receptor-targeted therapy in metastatic colorectal cancer. J Natl Cancer Inst. 2009 Oct;101(19):1308-24. DOI: https://doi.org/10.1093/jnci/djp280
56. Danielsen SA, Lind GE, Bjornslett M, Meling GI, Rognum TO, Heim S, et al. Novel mutations of the suppressor gene PTEN in colorectal carcinomas stratified by microsatellite instability- and TP53 mutation-status. Hum Mutat. 2008;29(11):E25262. DOI: https://doi.org/10.1002/humu.20860

57. Razis E, Briasoulis E, Vrettou E, Skarlos DV, Papamichael D, Kostopoulos I, et al. Potential value of PTEN in predicting cetuximab response in colorectal cancer: an exploratory study. BMC Cancer. 2008 Aug;8:234. DOI: https://doi. org/10.1186/1471-2407-8-234

58. Sartore-Bianchi A, Martini M, Molinari F, Veronese S, Nichelatti M, Artale S, et al. PIK3CA mutations in colorectal cancer are associated with clinical resistance to EGFR-targeted monoclonal antibodies. Cancer Res. 2009;69(5):1851-7. DOI: https://doi.org/10.1158/0008-5472.CAN-08-2466

59. Ogino S, Liao X, Imamura Y, Yamauchi M, McCleary NJ, Ng K, et al. Predictive and prognostic analysis of PIK3CA mutation in stage III colon cancer intergroup trial. J Natl Cancer Inst. 2013;105(23):178998. DOI: https://doi.org/10.1093/jnci/djt298

60. Price TJ, Hardingham JE, Lee CK, Townsend AR, Wrin JW, Wilson K, et al. Prognostic impact and the relevance of PTEN copy number alterations in patients with advanced colorectal cancer (CRC) receiving bevacizumab. Cancer Med. 2013 Mar;2(3):277-85. DOI: https://doi.org/10.1002/cam4.75

61. Adjei AA. Blocking oncogenic Ras signaling for cancer therapy. J Natl Cancer Inst. 2001;93:106274. DOI: https://doi.org/10.1093/jnci/93.14.1062

62. Grothey A, Sargent D. Overall survival of patients with advanced colorectal cancer correlates with availability of fluorouracil, irinotecan, and oxaliplatin regardless of whether doublet or single-agent therapy is used first line. J Clin Oncol. 2005;23(36):94412. DOI: https://doi.org/10.1200/JCO.2005.04.4792

63. Karapetis CS, Khambata-Ford S, Jonker DJ, O'Callaghan CJ, Tu D, Tebbutt NC, et al. K-ras mutations and benefit from cetuximab in advanced colorectal cancer. N Engl J Med. 2008 Oct;359:1757-65. DOI: https://doi.org/10.1056/NEJMoa0804385

64. Douillard JY, Oliner KS, Siena S, Tabernero J, Burkes R, Barugel M, et al. Panitumumab-FOLFOX4 treatment and RAS mutations in colorectal cancer. N Engl J Med. 2013 Sep;369:1023-34. DOI: https://doi.org/10.1056/NEJMoa1305275

65. Ferreira CG, Aran V, Zalcberg-Renault I, Victorino $\mathrm{AP}$, Salem JH, Bonamino $\mathrm{MH}$, et al. KRAS mutations: variable incidences in a Brazilian cohort of 8,234 metastatic colorectal cancer patients. BMC Gastroenterol. 2014 Apr;14:73. DOI: https://doi. org/10.1186/1471-230X-14-73

66. Pereira AAL, Fernandes GDS, Braga GTP, Marchetti KR, Mascarenhas CDC, Gumz B, et al. Differences in pathology and mutation status among colorectal cancer patients younger than, older than, and of screening age. Clin Colorectal Cancer. 2020;19(4):e264-e71. DOI: https://doi. org/10.1016/j.clcc.2020.06.004 
67. Heinemann V, Von Weikersthal LF, Decker T, Kiani A, Vehling-Kaiser $\mathrm{U}$, Al-Batran SE, et al. FOLFIRI plus cetuximab versus FOLFIRI plus bevacizumab as first-line treatment for patients with metastatic colorectal cancer (FIRE-3): a randomised, open-label, phase 3 trial. Lancet Oncol. 2014;15(10):1065-75. DOI: https://doi. org/10.1016/S1470-2045(14)70330-4

68. Hong DS, Fakih MG, Strickler JH, Desai J, Durm GA, Shapiro Gl, et al. KRASG12C inhibition with sotorasib in advanced solid tumors. N Engl J Med. 2020 Sep;383:1207-17. DOI: https://doi. org/10.1056/NEJMoa1917239

69. Johnson ML, Ou SHI, Barve M, Rybkin II, Papadopoulos KP, Leal TA, et al. KRYSTAL-1: activity and safety of adagrasib (MRTX849) in patients with colorectal cancer (CRC) and other solid tumors harboring a KRAS G12C mutation. Eur J Cancer. 2020;138(Suppl 2):S2. DOI: https://doi. org/10.1016/S0959-8049(20)31077-7

70. Pereira AA, Rego JF, Morris V, Overman MJ, Eng C, Garrett CR, et al. Association between KRAS mutation and lung metastasis in advanced colorectal cancer. Br J Cancer. 2015;112:424-8. DOI: https://doi.org/10.1038/bjc.2014.619

71. Tol J, Nagtegaal ID, Punt CJ. BRAF mutation in metastatic colorectal cancer. N Engl J Med. 2009;361:98-9. DOI: https://doi.org/10.1056/NEJMc0904160

72. Jones JC, Renfro LA, Al-Shamsi HO, Schrock AB, Rankin A, Zhang BY, et al. (Non-V600) BRAF mutations define a clinically distinct molecular subtype of metastatic colorectal cancer. J Clin Oncol. 2017;35(23):2624-30. DOI: https://doi. org/10.1200/JCO.2016.71.4394

73. Farina-Sarasqueta A, Van Lijnschoten G, Moerland $E$, Creemers GJ, Lemmens V, Rutten HJT, et al. The BRAF V600E mutation is an independent prognostic factor for survival in stage II and stage III colon cancer patients. Ann Oncol. 2010 Dec;21(12):2396-402.

74. Gray RG, Quirke P, Handley K, Lopatin M, Magill L, Baehner $\mathrm{FL}$, et al. Validation study of a quantitative multigene reverse transcriptase-polymerase chain reaction assay for assessment of recurrence risk in patients with stage II colon cancer. J Clin Oncol. 2011;29(35):4611-9. DOI: https://doi. org/10.1200/JCO.2010.32.8732

75. Van Cutsem E, Kohne CH, Lang I, Folprecht G, Nowacki MP, Cascinu S, et al. Cetuximab plus irinotecan, fluorouracil, and leucovorin as firstline treatment for metastatic colorectal cancer: updated analysis of overall survival according to tumor KRAS and BRAF mutation status. J Clin Oncol. 2011;29(15):2011-9. DOI: https://doi. org/10.1200/JCO.2010.33.5091

76. Price TJ, Hardingham JE, Lee CK, Weickhardt A, Townsend AR, Wrin JW, et al. Impact of KRAS and BRAF gene mutation status on outcomes from the phase III AGITG MAX trial of capecitabine alone or in combination with bevacizumab and mitomycin in advanced colorectal cancer. J Clin Oncol. 2011;29(19):2675-82. DOI: https://doi. org/10.1200/JCO.2010.34.5520
77. De Roock W, Claes B, Bernasconi D, De Schutter J, Biesmans B, Fountzilas $G$, et al. Effects of KRAS, BRAF, NRAS, and PIK3CA mutations on the efficacy of cetuximab plus chemotherapy in chemotherapy-refractory metastatic colorectal cancer: a retrospective consortium analysis. Lancet Oncol. 2010;11(8):753-62. DOI: https:// doi.org/10.1016/S1470-2045(10)70130-3

78. Kopetz S, Grothey A, Yaeger R, Van Cutsem E, Desai J, Yoshino T, et al. Encorafenib, binimetinib, and cetuximab in BRAF V600E-mutated colorectal cancer. N Engl J Med. 2019 Oct;381:1632-43. DOI: https://doi.org/10.1056/NEJMoa1908075

79. Hurwitz H, Fehrenbacher L, Novotny W, Cartwright T, Hainsworth J, Heim W, et al. Bevacizumab plus irinotecan, fluorouracil, and leucovorin for metastatic colorectal cancer. N Engl J Med. 2004 Jun;350:2335-42. DOI: https://doi. org/10.1056/NEJMoa032691

80. Hurwitz HI, Tebbutt NC, Kabbinavar F, Giantonio BJ, Guan ZZ, Mitchell L, et al. Efficacy and safety of bevacizumab in metastatic colorectal cancer: pooled analysis from seven randomized controlled trials. Oncologist. 2013 Jul;18(9):100412. DOI: https://doi.org/10.1634/theoncologist.2013-0107

81. Giantonio BJ, Catalano PJ, Meropol NJ, O'Dwyer PJ, Mitchell EP, Alberts SR, et al. Bevacizumab in combination with oxaliplatin, fluorouracil, and leucovorin (FOLFOX4) for previously treated metastatic colorectal cancer: results from the eastern cooperative oncology group study E3200. J Clin Oncol. 2007;25(12):1539-44. DOI: https://doi.org/10.1200/jco.2006.09.6305

82. Tabernero J, Yoshino T, Cohn AL, Obermannova R, Bodoky G, Garcia-Carbonero R, et al. Ramucirumab versus placebo in combination with second-line FOLFIRI in patients with metastatic colorectal carcinoma that progressed during or after first-line therapy with bevacizumab, oxaliplatin, and a fluoropyrimidine (RAISE): a randomised, double-blind, multicentre, phase 3 study. Lancet Oncol. 2015 May;16(5):499-508. DOI: https://doi. org/10.1016/S1470-2045(15)70127-0

83. Cutsem EV, Tabernero J, Lakomy R, Prenen $H$, Prausová J, Macarulla T, et al. Addition of aflibercept to fluorouracil, leucovorin, and irinotecan improves survival in a phase iii randomized trial in patients with metastatic colorectal cancer previously treated with an oxaliplatin-based regimen. J Clin Oncol. 2012;30(28):3499-506. DOI: https://doi.org/10.1200/jco.2012.42.8201

84. Isaksson-Mettavainio M, Palmqvist R, Dahlin AM, Van Guelpen B, Rutegard J, Oberg A, et al. High SMAD4 levels appear in microsatellite instability and hypermethylated colon cancers, and indicate a better prognosis. Int J Cancer. 2012 Sep;131(4):779-88. DOI: https://doi.org/10.1002/ ijc.26473 
85. Kim JH, Kang GH. Molecular and prognostic heterogeneity of microsatellite-unstable colorectal cancer. World J Gastroenterol. 2014 Apr;20(15):4230-43. DOI: https://doi. org/10.3748/wjg.v20.i15.4230

86. Li QH, Wang YZ, Tu J, Liu CW, Yuan YJ, Lin R, et al. Anti-EGFR therapy in metastatic colorectal cancer: mechanisms and potential regimens of drug resistance. Gastroenterol Rep (Oxf). 2020;8(3):179-91. DOI: https://doi.org/10.1093/gastro/goaa026

87. Sartore-Bianchi A, Trusolino L, Martino C, Bencardino K, Lonardi S, Bergamo F, et al. Dual-targeted therapy with trastuzumab and lapatinib in treatment-refractory, KRAS codon 12/13 wild-type, HER2-positive metastatic colorectal cancer (HERACLES): a proof-of-concept, multicentre, open-label, phase 2 trial. Lancet Oncol. 2016;17(6):738-46. DOI: https://doi.org/10.1016/ S1470-2045(16)00150-9

88. Bardelli A, Corso S, Bertotti A, Hobor S, Valtorta E, Siravegna G, et al. Amplification of the MET receptor drives resistance to anti-EGFR therapies in colorectal cancer. Cancer Discov. 2013;3(6):65873. DOI: https://doi.org/10.1158/2159-8290.CD$12-0558$

89. Hainsworth JD, Meric-Bernstam F, Swanton C, Hurwitz H, Spigel DR, Sweeney C, et al. Therapy for advanced solid tumors on the basis of molecular profiles: results from MyPathway, an open-label, phase lla multiple basket study. J Clin Oncol. 2018;36(6):536-42. DOI: https://doi. org/10.1200/JCO.2017.75.3780

90. Raghav K, Loree JM, Morris JS, Overman MJ, Yu $\mathrm{R}$, Meric-Bernstam F, et al. Validation of HER2 amplification as a predictive biomarker for anti-epidermal growth factor receptor antibody therapy in metastatic colorectal cancer. JCO Precision Oncol. 2019;226:1-13. DOI: https://doi. org/10.1200/PO.18.00226

91. Meric-Bernstam F, Hurwitz H, Raghav KPS, McWilliams RR, Fakih M, VanderWalde A, et al. Pertuzumab plus trastuzumab for HER2-amplified metastatic colorectal cancer (MyPathway): an updated report from a multicentre, open-label, phase 2a, multiple basket study. Lancet Oncol. 2019;20(4):518-30. DOI: https://doi.org/10.1016/S1470-2045(18)30904-5

92. Siena S, Bartolomeo MD, Raghav KPS, Masuishi T, Loupakis F, Kawakami H, et al. A phase II, multicenter, open-label study of trastuzumab deruxtecan (T-DXd; DS-8201) in patients (pts) with HER2-expressing metastatic colorectal cancer (mCRC): DESTINY-CRC01. J Clin Oncol. 2020;38(15 Suppl 1):4000. DOI: https://doi.org/10.1200/ JCO.2020.38.15_suppl.4000

93. Xu Y, Huang Z, Li C, Zhu C, Zhang Y, Guo T, et al. Comparison of molecular, clinicopathological, and pedigree differences between lynch-like and lynch syndromes. Front Genet. 2020;11:991. DOI: https://doi.org/10.3389/fgene.2020.00991
94. Domingo E, Freeman-Mills L, Rayner E, Glaire M, Briggs S, Vermeulen L, et al. Somatic POLE proofreading domain mutation, immune response, and prognosis in colorectal cancer: a retrospective, pooled biomarker study. Lancet Gastroenterol Hepatol. 2016;1(3):207-16. DOI: https://doi. org/10.1016/S2468-1253(16)30014-0

95. Mo S, Ma X, Li Y, Zhang L, Hou T, Han-Zhang $H_{\text {, }}$ et al. Somatic POLE exonuclease domain mutations elicit enhanced intratumoral immune responses in stage II colorectal cancer. J Immunother Cancer. 2020;8(2):e000881. DOI: https://doi. org/10.1136/jitc-2020-000881

96. Velcheti V, Schalper K. Basic overview of current immunotherapy approaches in cancer. ASCO Educ. 2016;36:298-308. DOI: https://doi. org/10.1200/edbk_156572

97. Feng D, Chen Z, He X, Huang S, Zhang Z. Loss of tumor intrinsic PD-L1 confers resistance to drug-induced apoptosis in human colon cancer. Neoplasma. 2020;68(1):144-53. DOI: https://doi. org/10.4149/neo_2020_200531N589

98. Wang S, Yuan B, Wang Y, Li M, Liu X, Cao J, et al. Clinicopathological and prognostic significance of PD-L1 expression in colorectal cancer: a meta-analysis. Int J Colorectal Dis. 2020 Sep;36:117-30. DOI: https://doi.org/10.1007/s00384-020-03734-4

99. Flavahan WA, Gaskell E, Bernstein BE. Epigenetic plasticity and the hallmarks of cancer. Science. 2017;357(6348):eaal2380. DOI: https://doi. org/10.1126/science.aal2380

100.Guinney J, Dienstmann R, Wang X, Reynies A, Schlicker A, Soneson C, et al. The consensus molecular subtypes of colorectal cancer. Nat Med. 2015 Oct;21:1350-6. DOI: https://doi. org/10.1038/nm.3967

101.Dolcetti R, Viel A, Doglioni C, Russo A, Guidoboni M, Capozzi E, et al. High prevalence of activated intraepithelial cytotoxic $\mathrm{T}$ lymphocytes and increased neoplastic cell apoptosis in colorectal carcinomas with microsatellite instability. Am J Pathol. 1999 Jun;154(6):1805-13.

102.Fessler E, Medema JP. Colorectal cancer subtypes: developmental origin and microenvironmental regulation. Trends Cancer. 2016 Sep;2(9):505-8. DOI: https://doi.org/10.1016/j. trecan.2016.07.008

103.Ogino S, Nosho K, Kirkner GJ, Kawasaki T, Meyerhardt JA, Loda M, et al. CpG island methylator phenotype, microsatellite instability, BRAF mutation and clinical outcome in colon cancer. Gut. 2009;58(1):90-6. DOI: https://doi.org/10.1136/ gut.2008.155473

104.Stintzing S, Wirapati P, Lenz HJ, Neureiter D, Von Weikersthal LF, Decker T, et al. Consensus molecular subgroups (CMS) of colorectal cancer (CRC) and first-line efficacy of FOLFIRI plus cetuximab or bevacizumab in the FIRE3 (AIO KRK-0306) trial. Ann Oncol. 2019 Nov;30(11):1796-803. 
105.Sousa EMF, Wang $X$, Jansen $M$, Fessler $E$, Trinh A, Rooij LP, et al. Poor-prognosis colon cancer is defined by a molecularly distinct subtype and develops from serrated precursor lesions. Nat Med. 2013 Apr;19:614-8. DOI: https://doi. org/10.1038/nm.3174

106.Alborelli I, Generali D, Jermann P, Cappelletti MR, Ferrero G, Scaggiante B, et al. Cell-free DNA analysis in healthy individuals by next-generation sequencing: a proof of concept and technical validation study. Cell Death Dis. 2019 Jul;10:534. DOI: https://doi.org/10.1038/s41419-019-1770-3

107.Chaudhuri AA, Chabon Jل Lovejoy AF, Newman AM, Stehr H, Azad TD, et al. Early detection of molecular residual disease in localized lung cancer by circulating tumor DNA profiling. Cancer Discov. 2017;7(12):1394-403. DOI: https://doi. org/10.1158/2159-8290.CD-17-0716

108.Tie J, Wang Y, Tomasetti C, Li L, Springer S, Kinde I, et al. Circulating tumor DNA analysis detects minimal residual disease and predicts recurrence in patients with stage II colon cancer. Sci Transl Med. 2016;8(346):346-92. DOI: https://doi. org/10.1126/scitranslmed.aaf6219

109.Phallen J, Sausen M, Adleff V, Leal A, Hruban $C$, White J, et al. Direct detection of early-stage cancers using circulating tumor DNA. Sci Transl Med. 2017;9(403):eaan2415. DOI: https://doi. org/10.1126/scitranslmed.aan2415

110.Frattini M, Gallino G, Signoroni S, Balestra D, Lusa L, Battaglia L, et al. Quantitative and qualitative characterization of plasma DNA identifies primary and recurrent colorectal cancer. Cancer Lett. 2008;263(2):170-181. DOI: https://doi. org/10.1016/j.canlet.2008.03.021

111.Thierry AR, Mouliere F, El Messaoudi S, Mollevi C, Lopez-Crapez E, Rolet F, et al. Clinical validation of the detection of KRAS and BRAF mutations from circulating tumor DNA. Nat Med. 2014 Mar;20:4305. DOI: https://doi.org/10.1038/nm.3511

112.Yang YC, Wang D, Jin L, Yao HW, Zhang JH, Wang J, et al. Circulating tumor DNA detectable in earlyand late-stage colorectal cancer patients. Biosci Rep. 2018;38(4):BSR20180322. DOI: https://doi. org/10.1042/BSR20180322

113.Bettegowda C, Sausen M, Leary RJ, Kinde I, Wang $Y$, Agrawal N, et al. Detection of circulating tumor DNA in early- and late-stage human malignancies. Sci Transl Med. 2014;6(224):224. DOI: https://doi.org/10.1126/scitranslmed.3007094

114.Clifton K, Rich TA, Parseghian C, Raymond VM, Dasari $A$, Pereira $A A L$, et al. Identification of actionable fusions as an anti-EGFR resistance mechanism using a circulating tumor DNA assay. JCO Precision Oncol. 2019;3. DOI: https:// doi.org/10.1200/PO.19.00141

115. Reinert T, Henriksen TV, Christensen E, Sharma $\mathrm{S}$, Salari R, Sethi $\mathrm{H}$, et al. Analysis of plasma cellfree DNA by ultradeep sequencing in patients with stages I to III colorectal cancer. JAMA Oncol. 2019;5(8):1124-31. DOI: https://doi.org/10.1001/ jamaoncol.2019.0528
116.Parseghian CM, Loree JM, Morris VK, Liu X, Clifton KK, Napolitano S, et al. Anti-EGFR-resistant clones decay exponentially after progression: implications for anti-EGFR re-challenge. Ann Oncol. 2019 Feb;30(2):243-9.

117.Dasari A, Morris VK, Allegra CJ, Atreya C, Benson $A B$, Boland $P$, et al. ctDNA applications and integration in colorectal cancer: an $\mathrm{NCl}$ Colon and Rectal-Anal Task Forces whitepaper. Nat Rev Clin Oncol. 2020;17:757-70. DOI: https://doi. org/10.1038/s41571-020-0392-0

118.Dromain C, Beigelman C, Pozzessere C, Duran $\mathrm{R}$, Digklia A. Imaging of tumour response to immunotherapy. Eur Radiol Exp. 2020 Jan;4:2. DOI: https://doi.org/10.1186/s41747-019-0134-1

119.Fabrizio DA, George Junior TJ, Dunne RF, Frampton G, Sun J, Gowen K, et al. Beyond microsatellite testing: assessment of tumor mutational burden identifies subsets of colorectal cancer who may respond to immune checkpoint inhibition. J Gastrointest Oncol. 2018 Aug;9(4):610-7. DOI: https://doi.org/10.21037/jgo.2018.05.06

120.Goodman AM, Sokol ES, Frampton GM, Lippman SM, Kurzrock R. Microsatellite-stable tumors with high mutational burden benefit from immunotherapy. Cancer Immunol Res 2019;7(10):1570-3. DOI: https://doi.org/10.1158/2326-6066.CIR-19-0149

121.Li R, Han D, ShiJ, Han Y, Tan P, Zhang R, et al. Choosing tumor mutational burden wisely for immunotherapy: a hard road to explore. Biochim Biophys Acta Rev Cancer. 2020;1874(2):188420. DOI: https://doi.org/10.1016/j.bbcan.2020.188420

122.Eso Y, Seno H. Current status of treatment with immune checkpoint inhibitors for gastrointestinal, hepatobiliary, and pancreatic cancers. Therap Adv Gastroenterol. 2020;13:1756284820948773. DOI: https://doi. org/10.1177/1756284820948773

123. Marabelle A, Fakih M, Lopez J, Shah M, Shapira-Frommer R, Nakagawa K, et al. Association of tumour mutational burden with outcomes in patients with advanced solid tumours treated with pembrolizumab: prospective biomarker analysis of the multicohort, open-label, phase 2 KEYNOTE-158 study. Lancet Oncol. 2020;21(10):1353-65. DOI: https://doi. org/10.1016/S1470-2045(20)30445-9

124.Xavier JB, Young VB, Skufca J, Ginty F, Testerman T, Pearson AT, et al. The cancer microbiome: distinguishing direct and indirect effects requires a systemic view. Trends Cancer. 2020 Mar;6(3):192-204. DOI: https://doi.org/10.1016/j.trecan.2020.01.004

125.Gopalakrishnan V, Spencer CN, Nezi L, Reuben A, Andrews MC, Karpinets TV, et al. Gut microbiome modulates response to anti-PD-1 immunotherapy in melanoma patients. Science. 2018;359(6371):97-103. DOI: https://doi. org/10.1126/science.aan4236

126. Matson V, Fessler J, Bao R, Chongsuwat T, Zha $Y$, Alegre $M L$, et al. The commensal microbiome is associated with anti-PD-1 efficacy in metastatic melanoma patients. Science. 2018;359(6371):104-8. DOI: https://doi. org/10.1126/science.aao3290 
127.Flanagan L, Schmid J, Ebert M, Soucek P, Kunicka T, Liska V, et al. Fusobacterium nucleatum associates with stages of colorectal neoplasia development, colorectal cancer and disease outcome. Eur J Clin Microbiol Infect Dis. 2014 Mar;33:1381-90. DOI: https://doi.org/10.1007/s10096-014-2081-3

128. Mima K, Nishihara R, Qian ZR, Cao Y, Sukawa $Y$, Nowak JA, et al. Fusobacterium nucleatum in colorectal carcinoma tissue and patient prognosis. Gut. 2016;65(12):1973-80. DOI: https://doi. org/10.1136/gutjnl-2015-310101

129.Chen W, Liu F, Ling Z, Tong X, Xiang C. Human intestinal lumen and mucosa-associated microbiota in patients with colorectal cancer. PLoS One. 2012;7(6):e39743, DOI: https://doi.org/10.1371/ journal.pone.0039743
130.Johnson $C H$, Dejea CM, Edler D, Hoang LT, Santidrian AF, Felding $\mathrm{BH}$, et al. Metabolism links bacterial biofilms and colon carcinogenesis. Cell Metab. 2015 Jun;21(6):891-7. DOI: https://doi. org/10.1016/j.cmet.2015.04.011

131.Pleguezuelos-Manzano C, Puschhof J, Huber RA, Van Hoeck A, Wood HM, Nomburg J, et al. Mutational signature in colorectal cancer caused by genotoxic pks+ E. coli. Nature. 2020 Feb;580:269-73. DOI: https://doi.org/10.1038/s41586-020-2080-8

132.Lee-Six H, Olafsson S, Ellis P, Osborne RJ, Sanders MA, Moore L, et al. The landscape of somatic mutation in normal colorectal epithelial cells. Nature. 2019 Oct;574:532-7. DOI: https://doi. org/10.1038/s41586-019-1672-7 